\title{
Urinary iron loss in the nephrotic syndrome-an unusual cause of iron deficiency with a note on urinary copper losses
}

\author{
E. A. BROWN \\ D.M., M.R.C.P. \\ B. R. MULLER \\ M.I.Biol., M.C.B.
}

B. SAMPSON

B.Sc., M.Phil.

J. R. CURTIS*
M.D. F.R.C.P.

Departments of Chemical Pathology and Medicine, Charing Cross Hospital Medical School, London W6 8RF

\begin{abstract}
Summary
Two patients with long-standing nephrotic syndrome are described in whom urinary iron losses may have contributed towards an iron deficiency state. Seven other nephrotic patients were also studied. Increased urinary iron excretion was found in six out of nine patients and increased urinary copper excretion in all eight patients in whom it was measured. Trace metal losses in the urine in nephrotics may be important clinically.
\end{abstract}

KEY WORDS: anaemia, ferritin, glomerulonephritis.

\section{Introduction}

There have been isolated case reports of iron deficiency anaemia in patients with the nephrotic syndrome which have been attributed to excessive urinary losses of transferrin and iron (Heilmeyer $e$ al., 1966; Hancock, Onstad and Wolf, 1976; Ellis, 1977). We report two patients with nephrotic syndrome where excessive urinary iron loss probably contributed to iron deficiency. Studies on a further seven patients with nephrotic syndrome including excretion of iron and copper are reported.

\section{Case reports}

\section{Case 1}

A white male, aged 56 years, presented with nephrotic syndrome in 1977. At presentation, the urine protein excretion was $9.5 \mathrm{~g} / 24 \mathrm{hr}$ and the plasma albumin $20 \mathrm{~g} / 1$. The ${ }^{51} \mathrm{Cr}$ EDTA clearance was $83 \mathrm{ml} / \mathrm{min}$. A renal biopsy showed membranous glomerulonephritis. A search for an associated neoplasm was negative and investigations included a normal chest X-ray, barium meal and barium enema.

\footnotetext{
*Principal author: Dr J. R. Curtis
}

Tests for carcinoembryonic antigen were negative and a full blood count was normal. The patient was treated with frusemide and followed regularly in outpatients. Blood counts remained normal until 1981 when the mean corpuscular haemoglobin $(\mathrm{MCH})$ fell to $25 \mathrm{pg}$ although the haemoglobin concentration and mean cell volume (MCV) were normal. The serum ferritin was $<5 \mu \mathrm{g} / 1$ on two occasions. Three stool specimens were negative for occult blood in November 1981 and a further three specimens were negative in December 1981. A further barium meal and barium enema were again normal. The ${ }^{51} \mathrm{Cr}$ EDTA clearance had fallen to $31 \mathrm{ml} / \mathrm{min}$. The urine protein excretion at this time was $11.4 \mathrm{~g} / 24 \mathrm{hr}$ with a transferrin excretion of $0.7 \mathrm{~g} / 24 \mathrm{hr}$ and a urinary iron excretion of $8.0 \mu \mathrm{mol} / 24 \mathrm{hr}$. The plasma albumin was $36 \mathrm{~g} / \mathrm{l}$. The patient was treated with oral iron (Feospan $1 \mathrm{bd}$ ) and over the next 3 months the $\mathrm{MCH}$ and serum ferritin levels returned to normal.

\section{Case 2}

An Asian female, aged 46 years, presented with nephrotic syndrome in 1979 when the urine protein excretion was $2.6 \mathrm{~g} / 24 \mathrm{hr}$ and the plasma albumin 25 $\mathrm{g} / \mathrm{l}$. The ${ }^{51} \mathrm{Cr}$ EDTA clearance was $98 \mathrm{ml} / \mathrm{min}$. A renal biopsy showed membranous glomerulonephritis. There was no evidence of an associated neoplasm. A chest X-ray and barium meal were normal. In 1982, an anaemia was noted with a haemoglobin of $9 \mathrm{~g} / \mathrm{dl}$, MCH $26 \mathrm{pg}$ and an MCV of $85 \mathrm{fl}$. The ${ }^{51} \mathrm{Cr}$ EDTA clearance had fallen to $23 \mathrm{ml} / \mathrm{min}$. Menstruation was regular and considered to be normal. Three stool specimens for occult blood were negative. A barium meal and follow-through examination were normal. A bone marrow aspirate showed reduced iron in macrophages and no iron in developing erythroblasts. The direct Coombs test was negative. The sickle 
test was negative. Serum and red cell folate and serum vitamin $B_{12}$ levels were normal. Dietary assessment indicated adequate intakes of iron, vita$\min B_{12}$ and folates, but with a high fibre and phytate diet which could interfere with the absorption of iron. A double isotope Schilling test was normal. The serum ferritin was $<5 \mu \mathrm{g} / \mathrm{l}$. The urine protein excretion at this time was $8 \mathrm{~g} / 24 \mathrm{hr}$ with a transferrin excretion of $0.52 \mathrm{~g} / 24 \mathrm{hr}$ and a urinary iron excretion of $2.6 \mu \mathrm{mol} / 24 \mathrm{hr}$. The plasma albumin was $25 \mathrm{~g} / \mathrm{l}$. The patient was treated with oral iron (ferrous gluconate $300 \mathrm{mg}$ tds) and over the next 3 months the $\mathrm{MCH}$ and serum ferritin levels returned to normal. The patient still had a normochromic normocytic anaemia presumably due to the chronic renal failure.

\section{Further studies}

\section{Methods}

Seven other patients with nephrotic syndrome were studied and $24 \mathrm{hr}$ urine collections made for determination of urine protein, transferrin, iron and copper. Blood samples were taken for estimation of plasma iron, ferritin, transferrin, albumin and copper. The urine collection containers were cleaned before use by soaking in $10 \%(\mathrm{v} / \mathrm{v})$ nitric acid and then extensively rinsed with deionized water. They were subsequently shown to be essentially iron and copper free. Serum albumin was measured on a Technicon 'Quantachem', serum and urine transferrin by immunonephelometry and total urine protein by the biuret reaction after trichloroacetic acid precipitation. Serum iron was measured by an 'AutoAnalyser' procedure using 2, 4, 6, -tri-(2'-pyridyl)- 1, 3, 5, -tridzine (TPTZ), urine iron was measured by a manual procedure using ferene-S, serum and urine copper were measured by atomic absorption spectroscopy. Serum ferritin was measured by radioimmunoassay.

\section{Results}

Details of the patients including age, sex, underlying renal diagnosis and duration of nephrotic syn- drome are shown in Table 1. Five patients were 3 considered to have idiopathic membranous glomeru- $\stackrel{\varnothing}{\complement}$ lonephritis, two had minimal change glomerulone- $C$. phritis, one had membranous glomerulonephritis $\Rightarrow$ secondary to penicillamine treatment for rheumatoid $\stackrel{5}{7}$ arthritis and one had idiopathic focal glomerulosclerosis.

The results of plasma and urine estimations are $\frac{\bar{s}}{\sigma}$ shown in Tables 2 and 3. The plasma albumin was $\cong$ below normal in six out of nine patients at the time of the study. The plasma transferrin was reduced in one $\vec{\circ}$ out of five in whom it was measured. There was a significant negative correlation between the plasma $\vec{\omega}$ transferrin and urine transferrin excretion $\stackrel{\rho}{\circ}$ $(P<0.005)$. Plasma iron was reduced in $2 / 8$ patients. $\frac{8}{7}$ Plasma copper was reduced in 1/6. Urine iron 3 . excretion was raised in $6 / 9$ patients and urine copper 8 excretion raised in all eight patients. Both urinary transferrin excretion $(P<0.001)$ and urinary copper 0 excretion $(P<0.001)$ were significantly correlated $\vec{N}$ with urinary protein excretion. With the exception of $\mathcal{G}$ case 1 and case 2 , none of the other seven patients 5 had any evidence of iron deficiency. The serum $\overrightarrow{-}$ ferritin was normal in three of the seven patients and ${ }_{\mathbb{D}}^{T}$ raised in one patient.

\section{Discussion}

Increased urinary excretion of iron in the nephrot syndrome has been reported by a number of workef Wiltink et al. (1972) recorded mean urinary iron losses of 1.3 and $5.4 \mu \mathrm{mol} / 24 \mathrm{hr}$ in two nephrotic patients compared with a mean of $0.06 \mu \mathrm{mol} / 24 \mathrm{hr}$ in normal controls. These authors doubted whether an $\frac{\circ}{\varnothing}$

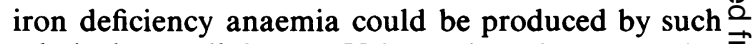
relatively small losses. Urinary iron loss was also $\overrightarrow{\overrightarrow{0}}$ considered to be of minor importance with regard to 3 iron deficiency anaemia by Jensen et al. (1968) who from turnover studies of radioiodinated transferrin in seven nephrotic patients calculated urinary iron losses varying from $1.4-8.5 \mu \mathrm{mol} / 24 \mathrm{hr}$. Increased urinary excretion of transferrin and iron were re- $\frac{3}{3}$ ported in two patients with nephrotic syndrome by

TABLE 1. Clinical details of patients

\begin{tabular}{ccclc}
\hline Patient & Sex & $\begin{array}{c}\text { Age } \\
\text { (years) }\end{array}$ & \multicolumn{1}{c}{ Diagnosis } & $\begin{array}{c}\text { Duration of nephrotic } \\
\text { syndrome }\end{array}$ \\
\hline Case 1 & M & 56 & Membranous GN & 5 years \\
Case 2 & F & 46 & Membranous GN & 4 years \\
A & M & 40 & Membranous GN & 5 months \\
B & M & 70 & Membranous GN & 7 months \\
C & F & 49 & Membranous GN & 12 years \\
D & F & 58 & Penicillamine-induced & 3 months \\
& & & membranous GN & 2 months \\
E & F & 32 & Minimal change GN & 3 months \\
F & M & 64 & Focal glomerulosclerosis & 3 months \\
G & M & 55 & Minimal change GN &
\end{tabular}

$\mathrm{GN}=$ glomerulonephritis. 
TABLE 2. Results of plasma estimations

\begin{tabular}{cccccc}
\hline Patient & $\begin{array}{c}\text { Albumin } \\
(\mathrm{g} / \mathrm{l})\end{array}$ & $\begin{array}{c}\text { Transferrin } \\
(\mathrm{g} / \mathrm{l})\end{array}$ & $\begin{array}{c}\text { Iron } \\
(\mu \mathrm{mol} / \mathrm{l})\end{array}$ & $\begin{array}{c}\text { Ferritin } \\
(\mu \mathrm{g} / \mathrm{l})\end{array}$ & $\begin{array}{c}\text { Copper } \\
(\mu \mathrm{mol} / \mathrm{l})\end{array}$ \\
\hline Case 1 & 36 & - & - & $<5$ & - \\
Case 2 & 25 & $2 \cdot 5$ & 6 & $<5$ & - \\
A & 33 & - & 21 & 22 & $16 \cdot 0$ \\
B & 25 & $1 \cdot 2$ & 5 & 138 & $10 \cdot 0$ \\
C & 35 & $2 \cdot 1$ & 15 & - & $16 \cdot 0$ \\
D & 29 & $1 \cdot 9$ & 11 & 27 & $16 \cdot 6$ \\
E & 25 & - & 14 & - & $13 \cdot 6$ \\
F & 22 & - & 17 & 492 & - \\
G & 40 & $2 \cdot 8$ & 22 & $-23 \cdot 0$ \\
Normal & & $1 \cdot 8-3 \cdot 3$ & $11-32$ & $10-300 \mathrm{~F}$ & $12-20$ \\
range & $35-45$ & & & & \\
\hline
\end{tabular}

TABLE 3. Results of urine ( $24 \mathrm{hr})$ estimations

\begin{tabular}{ccccc}
\hline Patient & $\begin{array}{c}\text { Total protein } \\
(\mathrm{g})\end{array}$ & $\begin{array}{c}\text { Transferrin } \\
(\mathrm{g})\end{array}$ & $\begin{array}{c}\text { Iron } \\
{[\mu \mathrm{g}(\mu \mathrm{mol})]}\end{array}$ & $\begin{array}{c}\text { Copper } \\
(\mu \mathrm{mol})\end{array}$ \\
\hline Case 1 & $11 \cdot 4$ & $0 \cdot 7$ & $446(8 \cdot 0)$ & - \\
Case 2 & $8 \cdot 0$ & $0 \cdot 52$ & $145(2 \cdot 6)$ & $1 \cdot 9$ \\
A & $2 \cdot 5$ & $0 \cdot 24$ & $89(1 \cdot 6)$ & $1 \cdot 3$ \\
B & $29 \cdot 5$ & $1 \cdot 21$ & $440(7 \cdot 9)$ & $4 \cdot 2$ \\
C & $5 \cdot 8$ & $0 \cdot 2$ & $172(3 \cdot 1)$ & $2 \cdot 5$ \\
D & $3 \cdot 4$ & $0 \cdot 12$ & $94(1 \cdot 7)$ & $1 \cdot 5$ \\
E & $3 \cdot 3$ & $0 \cdot 1$ & $156(2 \cdot 8)$ & $1 \cdot 1$ \\
F & $12 \cdot 3$ & $0 \cdot 8$ & $1099(19 \cdot 7)$ & $3 \cdot 3$ \\
G & $3 \cdot 1$ & $0 \cdot 14$ & $111(2 \cdot 0)$ & $2 \cdot 0$ \\
Normal & & - & - & $<1 \cdot 0$ \\
range & - & - & - & \\
\hline
\end{tabular}

Normal values from Dagg et al. (1966). Nine normal males, mean $69 \mu \mathrm{g} / 24 \mathrm{hr}$ (s.d. $\pm 19 \cdot 2)$ or $1.25 \mu \mathrm{mol} / 24 \mathrm{hr} \pm 0.34 ; 13$ normal females, mean $74 \mu \mathrm{g} / 24 \mathrm{hr}(\mathrm{s} . \mathrm{d} . \pm 22.6)$ or $1.33 \mu \mathrm{mol} / 24 \mathrm{hr} \pm 0.40$.

Rifkind et al. (1961). Dagg, Smith and Goldberg (1966) in an extensive study of the urinary excretion of iron reported a mean urinary excretion of 1.25 $\mu \mathrm{mol} / 24 \mathrm{hr}( \pm 0 \cdot 34$ s.d.) in nine normal males and a mean of $1.33 \mu \mathrm{mol} / 24 \mathrm{hr}( \pm 0.40$ s.d. $)$ in 13 normal females. In 12 patients with proteinuria, including 10 with the nephrotic syndrome, they demonstrated a considerable increase in urinary iron losses varying from $1 \cdot 25-17.8 \mu \mathrm{mol} / 24 \mathrm{hr}$. A significant positive correlation between the urinary excretion of iron and $\beta$-globulin was demonstrated and a less significant positive correlation between the urinary excretion of iron and total urinary protein, supporting the finding of Rifkind et al. (1961) that urinary iron loss in nephrotic syndrome is due to urinary loss of transferrin. Dagg et al. (1966) also suggest that urinary iron losses may have contributed to the iron deficiency anaemia in one of their patients.

In the present study, urinary iron losses were raised above the normal values reported by Dagg et al. (1966) in six out of nine nephrotic patients. There was however no significant correlation between urinary iron excretion and urinary protein excretion. In the two patients reported it seems likely that the urinary iron losses may have contributed in part at least to an iron deficiency state. The duration of the nephrotic syndrome may well be relevant. Both patients had had nephrotic syndrome for several years. Six of the seven other patients had only had nephrotic syndrome for several months although the remaining patient had no evidence of iron deficiency despite having had nephrotic syndrome for 12 years. There is evidence of increased urinary losses of other metals in the nephrotic syndrome. Increased urinary losses of zinc have been reported (Lindeman et al., 1978; Temes-Montes et al., 1980). In the present study, urinary copper excretion was raised in all eight patients in whom it was measured and there was a significant positive correlation between the urinary copper excretion and the total urine protein excretion. The plasma copper concentration was reduced in only one of the six patients. It is known however that plasma copper concentration gives a poor indication of total body copper (Oski, 1970; Klein, Metz and Price, 1972). The significance of urinary losses of trace elements such as zinc and copper in patients with long-standing nephrotic syndrome is not known, but it is possible that signs of clinical deficiency of these trace elements may be produced including anaemia (Aggett, 1979). Mahajan et al. (1983) have studied zinc metabolism in the nephrotic syndrome. These authors found low plasma zinc levels which they attributed to a combination of increased urinary zinc losses and to a decreased zinc intake. The zinc deficiency in their patients was associated with evidence of hypogeusia. In longstanding nephrotic syndrome, urinary iron losses may contribute however towards an iron deficiency state.

\section{Acknowledgments}

We wish to thank the Department of Haematology, Charing Cross Hospital Medical School for numerous blood counts and in particular Miss Joan Shepherd for the serum ferritin determinations. 


\section{References}

AggetT, P.J. (1979) Trace elements in medicine. Hospital Update, November, 981.

DAGG, J.H., SMITh, J.A. \& GoldberG, A. (1966) Urinary excretion of iron. Clinical Science, 30, 495.

ElLIS, D. (1977) Anemia in the course of the nephrotic syndrome secondary to transferrin depletion. Journal of Pediatrics, 90, 953.

HanCOCK, D.E., ONSTAD, J.W. \& WolF, P.L. (1976) Transferrin loss into the urine with hypochromic, microcytic anemia. American Journal of Clinical Pathology, 65, 73.

Heilmeyer, L., Merker, H., Wetzerl, J.P., Klemm, D., BurMEISTER, P.K. \& HAAS, R. (1966) Transferrin deficiency associated with nephrotic syndrome. German Medical Monthly, 11, 219.

Jensen, J., Bro-Jorgensen, K., Jarnum, S., Olesen, H. \& Yssing, M. (1968) Transferrin metabolism in the nephrotic syndrome and in protein losing gastroenteropathy. Scandinavian Journal of Clinical and Laboratory Investigation, 21, 293.

Klein, W.J., MetZ, E.M. \& Price, A.R. (1972) Acute copper intoxication. A hazard of hemodialysis. Archives of Internal Medicine, 129, 578.
Lindeman, R.D., BAXTER, D.J., YUNiCe, A.A. \& KRaIKITPANITCI S. (1978) Serum concentrations and urinary excretion of zinc $B$ cirrhosis, nephrotic syndrome and renal insufficiency. American Journal of the Medical Sciences, 275, 17.

Mahajan, S., Speck, J., Varghese, G., Abu-Hamdan, D., Mic Dal, S., Briggs, W., Prasad, A. \& McDonald, F. (1983) Ziric metabolism in nephrotic syndrome. Kidney International, 23, 12 OsK1, F.A. (1970) Chickee, the copper. Annals of Internal Medicine. 73, 485 .

Rifkind, D., Krauetz, H.M., KNight, V. \& Schade, A.L. (196 Urinary excretion of iron-binding protein in the nephrot? syndrome. New England Journal of Medicine, 265, 115.

Temes-Montes, X.L., Picaporte, M.A., Herrero, E., Selgas, R Beberide, J.M., Martinez-Aray, J. \& SANCHEZ-Sicilia, (1980) Valores séricos y urinarios de cinc en nefropatiás exteriorit zadas por sindrome nefrotico o como proteinuria en rangos nefrotico. Revista clinica Espanola, 159, 159.

Wiltink, W.F., Van EiJK, H.G., Bobeck-RutSaert, M.M., GeP BRANDY, J. \& LEIJNSE, B. (1972) Urinary iron excretion in nephrotic syndrome. Acta Haematologica, 47, 269.

(Accepted 9 June 1983) 